\title{
Introduction of HPV prophylactic vaccines: A new challenge for Public Health in the $21^{\text {st }}$ century
}

\author{
Luisa Lina Villa \\ Ludwig Institute for Cancer Research, São Paulo, Brazil \\ Ilvilla@ludwig.org.br
}

Cervical cancer affects almost half million women each year worldwide, $70 \%$ of them living in developing countries. If current trends continue, this number will almost double in 2,020 (Parkin \& Bray, 2006). Primary prevention with a very effective vaccine could change this scenario dramatically. However, the present cost of the vaccines as well as the lack of information, policies and implementation strategies may hinder its broad application, particularly in low-resource settings where it is most needed.

\section{Current evidence-based medicine}

Several clinical trials of two prophylactic HPV vaccines have been conducted in different countries including about 50,000 individuals. The per-protocol populations included women who were naïve at baseline to HPV 16 and 18, or to HPV 6, 11, 16, and 18 , as determined by serology testing for the presence of HPV type-specific antibodies or polymerase chain reaction (PCR) testing of genital samples for the presence of HPV DNA (Harper et al., 2004; Villa et al., 2005). For both the bivalent and quadrivalent vaccines, results of different trials allow for the examination of broad trends in efficacy in preventing HPV 6/11/16/18-related disease in several groups of patients classified according to their HPV status at baseline. The quadrivalent vaccine was $100 \%$ effective in reducing the incidence of HPV 6/11/16/18-related disease in women who were serologically and DNA PCR negative at baseline to the relevant HPV type, as well as in women who had been previously exposed to at least 1 HPV type vaccine at enrollment, but had no ongoing HPV infection (i.e., seropositive but HPV DNA negative by PCR) (Future II study group, 2007; Garland et al., 2007). However, there was no clear evidence of protection from disease caused by HPV types for subjects that were HPV DNA positive by PCR and/or seropositive at baseline (Ault et al., 2007; Joura et al., 2007). Similar results were obtained for the bivalent vaccine (Harper et al., 2005 and 2006). In fact, vaccination of HPV16/18 DNA positive women does not enhance clearance of the viral infection (Hildesheim et al., 2007). In a recent publication of a phase III trial, this bivalent vaccine showed $90 \%$ prophylactic efficacy against CIN2+ associated with HPV 16 or HPV 18 (Paavonen et al., 2007).

\section{Challenges for HPV vaccine introduction}

Based on its demonstrated clinical efficacy and favorable safety profile, HPV prophylactic vaccines are being introduced in many countries around the World. In several developing countries, including among others, Brazil, Chile, Mexico, Peru, the Quadrivalent HPV 6, 11, 16, 18 vaccine has been in use for more than 1 year. The rapid approval and launch of such vaccines provide a clear indication that governments and policy makers are aware of the expected impact on the prevention of one of the most common causes of female mortality worldwide. However, incorporation of HPV vaccination in the public health sector is 
still to be seen in the developing World, mostly due to vaccine cost. HPV vaccine implementation will also depend on local infrastructure for vaccine delivery to the initial target population during the window of highest vaccine efficacy, i.e. prior to sexual exposure. Furthermore, introducing HPV vaccines in the present cervical cancer control system is hampered by the fact that secondary screening with Pap tests (or HPVDNA testing) will still be required to detect cervical cancers and pre-cancers caused by non-vaccine HPV types. Ongoing cost-benefit studies and negotiations between governments, the private sector, and non-governmental organizations may enable some of the developing countries, where the vaccine is most needed, to implement the necessary programs. Education of physicians, policy makers, parents, and adolescents will be crucial for delivering HPV vaccines, which ultimately will result in the reduction of cervical cancer rates and other HPV-related diseases worldwide. Vaccine acceptance is largely determined by health beliefs, such as the individual's perceived susceptibility to the disease; vaccine characteristics, such as cost and efficacy; and obstacles to obtain the vaccine. Health perceptions are expected to play a major role in the acceptance of HPV vaccine, as is the fact that the vaccine raises the morally and politically charged issue of adolescent sexual behavior. Physicians' attitudes are extremely influential to both parents and adolescents, and physicians' perception regarding the HPV vaccine as important and recommended will be a critical step towards vaccine acceptance. Altogether, education of physicians, parents, and adolescents will be crucial for delivering HPV vaccines to target populations during the window of highest vaccine efficacy, prior to sexual debut.

Despite these excellent efficacy results, it may take some time before these vaccines are administered to the general population worldwide. Moreover, women will still be at risk for developing cancers caused by other HPV types not included in the vaccine and hence screening and monitoring strategies will be required. Finally, since at present the durability of these vaccines has been evaluated only for up to 5 years (Harper et al., 2006, Villa et al., 2006), monitoring of antibody levels and high grade disease caused by the HPV vaccine types in sentinel groups of immunized individuals will be required over the next decades (Lehtinen et al., 2006). It is important to stress that disease outcomes should be recorded since at present there is no immune correlate and the importance of serum antibody levels is simply not known. To achieve this, standardized methodologies that measure total serum antibody, neutralizing antibody and type specific antibody concentrations will be necessary. However, at present neither HPV serological assays nor HPV DNA tests can be used as clinically relevant tools for individual patients. These assays will require the establishment of International Standard(s) with an arbitrarily assigned unit measure or International Units (http://www.who.int/ biologicals/areas/vaccines/hpv_labnet/en/ index.html and Ferguson et al., 2006).

The availability of two prophylactic HPV vaccines will require thorough considerations on monitoring and surveillance of those vaccinated and of the general population, respectively (Stanley \&Villa, 2008).Vaccinated populations should be followed-up for longterm safety, sustained immune responses and vaccine disease efficacy (Dillner et al., 2007). Effective monitoring will benefit from linkage of vaccination history and screening history, as well as precise measurement of HPV infection, plus both DNA and serological testing. Lack of record linkage in many settings is one of the main obstacles for an effective surveillance program, though other surveillance activities can contribute to assessing HPV vaccine efficacy, including information from organized screening programs and phase IV studies. Importantly, loss of screening performance may occur because of the expected reduction in cervical abnormalities in vaccinated populations. In this scenario, HPV testing has the potential to perform better as a primary screening test, followed by cytology for triage of HPV-positive cases (Franco et al., 2006).

Disclosed potential conflict of interest: Steering committee Merck and Co., Inc 


\section{References}

Ault KA; Future II Study Group. Effect of prophylactic human papillomavirus L1 virus-like-particle vaccine on risk of cervical intraepithelial neoplasia grade 2 , grade 3 , and adenocarcinoma in situ: a combined analysis of four randomised clinical trials. Lancet. 2007 Jun 2;369(9576):1861-8.

Dillner J, Arbyn M, Dillner L. Translational Mini-Review Series on Vaccines: Monitoring of human papillomavirus vaccination. Clin Exp Immunol 2007; 148:199-207.

Ferguson M, Heath A, Johnes S, Pagliusi S, Dillner J; Collaborative Study Participants. Results of the first WHO international collaborative study on the standardization of the detection of antibodies to human papillomaviruses. Int J Cancer. 2006 Mar 15;118(6):1508-14.

Franco EL, Cuzick J, Hildesheim A, Sanjose S. Issues in planning cervical cancer screening in the era of HPV vaccination. Vaccine 2006, 24S3: $171-7$

FUTURE II Study Group. Quadrivalent vaccine against human papillomavirus to prevent highgrade cervical lesions. N Engl J Med. 2007 May 10;356(19):1915-27.

Garland SM, Hernandez-Avila M, Wheeler CM, Perez G, Harper DM, Leodolter S, Tang GW, Ferris DG, Steben M, Bryan J, Taddeo FJ, Railkar R, Esser MT, Sings HL, Nelson M, Boslego J, Sattler C, Barr E, Koutsky LA; Females United to Unilaterally Reduce Endo/Ectocervical Disease (FUTURE) I Investigators. Quadrivalent vaccine against human papillomavirus to prevent anogenital diseases.

N Engl J Med. 2007 May 10;356(19):1928-43.

Harper DM, Franco EL, Wheeler C, Ferris DG, Jenkins D, Schuind A et al. Efficacy of a bivalent $\mathrm{L} 1$ virus-like particle vaccine in prevention of infection with human papillomavirus types 16 and 18 in young women: a randomised controlled trial. Lancet 2004;364:1757-65.

Harper DM, Franco EL, Wheeler CM, Moscicki $\mathrm{AB}$, Romanowski B, Roteli-Martins CM, Jenkins D, Schuind A, Costa Clemens SA, Dubin G; HPV Vaccine Study group. Sustained efficacy up to 4.5 years of a bivalent L1 virus-like particle vaccine against human papillomavirus types 16 and 18: follow-up from a randomised control trial. Lancet. 2006 Apr 15;367(9518):1247-55.

Hildesheim A, Herrero R, Wacholder S, Rodriguez AC, Solomon D, Bratti MC, Schiller
JT, Gonzalez P, Dubin G, Porras C, Jimenez SE, Lowy DR; Costa Rican HPV Vaccine Trial Group. Effect of human papillomavirus 16/18 L1 viruslike particle vaccine among young women with preexisting infection: a randomized trial. JAMA. 2007 Aug 15;298(7):743-53.

Joura EA, Leodolter S, Hernandez-Avila M, Wheeler CM, Perez G, Koutsky LA, Garland SM, Harper DM, Tang GW, Ferris DG, Steben M, Jones RW, Bryan J, Taddeo FJ, Bautista OM, Esser MT, Sings HL, Nelson M, Boslego JW, Sattler C, Barr E, Paavonen J. Efficacy of a quadrivalent prophylactic human papillomavirus (types 6, 11, 16, and 18) L1 virus-like-particle vaccine against high-grade vulval and vaginal lesions: a combined analysis of three randomised clinical trials. Lancet. 2007 May 19;369(9574):1693-702.

Lehtinen M, Herrero R, Mayaud P, Barnabas R, Dillner J, Paavonen J, Smith P. Studies to assess the long-term efficacy and effectiveness of HPV vaccination in developed and developing countries. Vaccine 2006, 24S3: S3/233-241.

Paavonen J, Jenkins D, Bosch FX, Naud P, Salmeron J, Wheeler CM, Chow SN, Apter DL, Kitchener HC, Castellsague X, de Carvalho NS, Skinner SR, Harper DM, Hedrick JA, Jaisamrarn U, Limson GA, Dionne M, Quint W, Spiessens B, Peeters P, Struyf F, Wieting SL, Lehtinen MO, Dubin G; for the HPV PATRICIA study group. Efficacy of a prophylactic adjuvanted bivalent L1 virus-like-particle vaccine against infection with human papillomavirus types 16 and 18 in young women: an interim analysis of a phase III double-blind, randomised controlled trial. Lancet. 2007 Jun 27; 369:2161-70

Parkin DM, Bray F. Chapter 2: the burden of HPV-related cancers. Vaccine. 2006 Aug 21;24 Suppl 3:S11-25.

Stanley M, Villa LL. Monitoring HPV vaccination.Vaccine. 2008 Mar 14;26 Suppl 1:A24-27.

Villa LL, Costa RL, Petta CA, Andrade RP, Ault KA, Giuliano AR et al. Prophylactic quadrivalent human papillomavirus (types 6, 11, 16, and 18) L1 virus-like particle vaccine in young women: a randomised double-blind placebo-controlled multicentre phase II efficacy trial. Lancet Oncol 2005;6:271-8.

Villa LL, Costa RL, Petta CA, Andrade RP, Paavonen J, Iversen OE et al. High sustained efficacy of a prophylactic quadrivalent human papillomavirus types 6/11/16/18 L1 virus-like particle vaccine through 5 years of follow-up. $\mathrm{Br}$ J Cancer 2006;95:1459-66. 